\title{
Corona Virus, Climate Change, and Food Security
}

\author{
Nkiru Theresa Meludu and Toyin Abolade
}

\section{Contents}

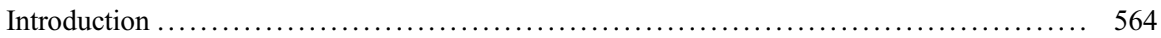

Conceptualizing the Pandemic Nature of Coronavirus .......................... 565

Symptoms Associated with COVID-19 (NCDC and Hopkins University 2020; WHO

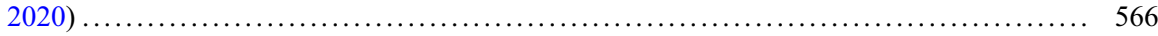

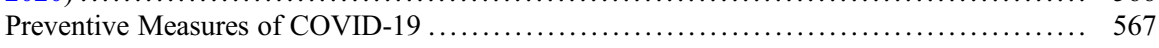

Strategies Implemented by the Government Globally to Control and Prevent the Spread of

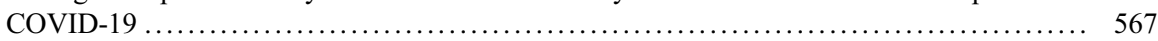

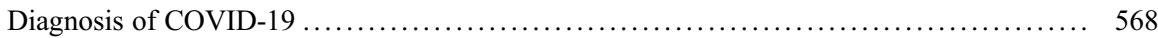

Transformation of Situations Causing Typical Climate Change ......................... 568

Effects of Weather Variation on the Environment and Agriculture in Nigeria ............ 569

Effects of Climate Change on Food Security .................................... 570

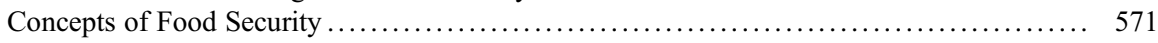

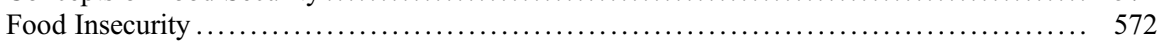

Effects of the Coronavirus 2019 (COVID-19) Pandemic and Climate Change on Food

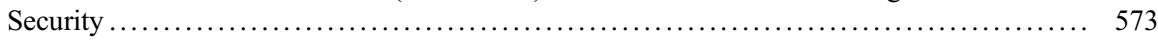

Empirical Evidences Obtained Through Online Survey on COVID-19 Awareness and

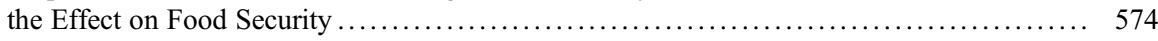

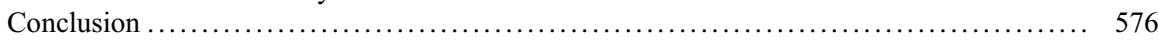

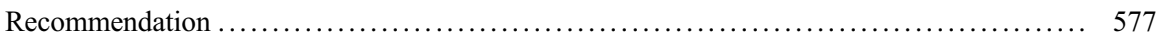

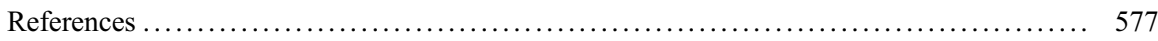

This chapter was previously published non-open access with exclusive rights reserved by the Publisher. It has been changed retrospectively to open access under a CC BY 4.0 license and the copyright holder is "The Author(s)". For further details, please see the license information at the end of the chapter.

\footnotetext{
N. T. Meludu $(\bowtie) \cdot$ T. Abolade

Department of Agricultural Economics and Extension Faculty of Agriculture, Nnamdi Azikiwe

University, Awka, Nigeria

e-mail: nt.meludu@unizik.edu.ng
} 


\section{Abstract}

Coronavirus disease of 2019 (COVID-19) is a current pandemic causing lockdown of cities and countries. The nature of this disease and the global cases are still considered as deadly all over the world. Analogous was drawn between the current COVID-19 pandemic and some of the other contemporary crises of the world as regards to climate change in addition to food shortage. Also, Survey Monkey instrument was used to generate emperical evidences from 514 respondents on covid-19 awareness and the effect on food security. Effects of diseases on climate change, such as the increasing frequency and strength of extreme weather events or the expanding range and spread of diseases was considered. Then, the relationship between the COVID-19 pandemic and climate change was investigated. Prior to the pandemic, climate change already had adverse effects on agriculture and vice versa, which led to food insecurity. The need for fruits as well as leafy and root vegetables in peri-urban and urban areas is increasing, as well as the food shortage. A drop in agricultural production will be expected in the future if the pandemic continues for a few more months. The perception and adherence to the preventive measures for this pandemic were determined to reduce its spread and lessen its effect on agricultural production as well as to improve food security.

\section{Keywords}

Covid-19 $\cdot$ Climate outcomes $\cdot$ Consequences $\cdot$ Agriculture $\cdot$ Food insecurity

\section{Introduction}

A total of 17 sustainable development goals (SDGs) have been set to transform our world, namely: no poverty, zero hunger, good health and well-being, quality education, gender equality, clean water and sanitation, affordable and clean energy, decent work and economic growth, industry, innovation and infrastucture, reduced inequality, sustainable cities and communities, responsible consumption and production, climate action, life below water, life on land, peace and justice strong institutions, partinership to achieve the goals (United Nations Department of Economic and Social Affairs (UNDESA) 2015).

SDGs are the organized principles for addressing environmental improvement objectives and sustaining the capacity of the usual structure to offer natural resources, flora and fauna services upon which the economy and humanity depends is crucial.

This chapter identified some of the issues influencing climate change and the effect of climate change on food security. It also discussed coronavirus disease 2019 (COVID-19), which is the current pandemic causing lockdown of the entire economy due to its global occurrence (World Health Organisation (WHO) 2020). Some 
emperical evidences were determined with the use of "Suervey Monkey" Instrument that generated responses from respondents from different parts different of Nigeria at the peak of the pandemic. This chapter highlighted the pandemic nature of COVID19 and other hidden evidences in litreature. Essentially, some of the health constraints on climate change include the increasing occurrence of extreme weather events and the growing rate and spread of illnesses, such as malaria.

COVID-19, a persistent respiratory disease caused by corona virus is transmitted chiefly by contact with human and infected surfaces and the individual shows symptom of fever, cough, and shortness of breath and may advance to pneumonia, respiratory failure and death.

Furthermore, the relationship between pandemic and climate change was investigated, although climate change already had adverse effects on agricultural production, which led to food insecurity, especially in under developed countries. It is expected that agricultural production will drop in the subsequent years if COVID-19 pandemic persists for more months. The vulnerable groups include small-scale farmers, migrants, labourers/workers, nomads, and fisher folks who have been prevented from working on their farms and from taking care of their animals/ fisheries will fell the effect. These groups also face difficulty in obtaining access to proper marketplaces to retail their produces and processed goods as a result of increased food prices and inadequate purchasing resources. Informal laborers are also affected leading to hike in labor cost and income losses because of delayed harvesting of the produce.

\section{Conceptualizing the Pandemic Nature of Coronavirus}

COVID-19 could be described as a respiration set of severe acute respiratory syndrome coronavirus 2 (SARS-CoV-2) (World Health Organization (2020). This virus spreads primarily between people during close contact, often through small drops of discharge from the nostrils once an infested individual sneezes or coughs into the air. The droplets usually drop to the ground/surfaces without being suspended in the air moving 2-m distances (Nigerian Centre for Disease Control (NCDC) 2020). People may contract the virus by touching polluted surfaces and then touching their faces (mouth, nose, and eyes). The first case of COVID-19 occurred in December 2019 in Wuhan, China's Hubei Province. Then, it subsequently spread globally, which resulted in the ongoing 2019-2020 coronavirus pandemic (Hui et al. 2020; World Health Organization (WHO) 2020). COVID-19 has an incubation period of usually 2-14 days for people who develop symptoms; however, some people who are infected do not develop any form of symptoms and are thus called asymptomatic. While it is easy to isolate and treat infected people that develop symptoms, the asymptomatic patients cannot be easily identified, isolated, and treated, thus posing a great risk of spreading of the virus. This brings fear to the people and also has crippled many economies worldwide, affecting agricultural 
production, thus causing food scarcity, hunger, and food insecurity. Interestingly, researchers worldwide are working tirelessly to develop vaccines/drugs and treatment regimes of the disease.

\section{Symptoms Associated with COVID-19 (NCDC and Hopkins University 2020; WHO 2020)}

1. Cough - Coughing is a common impulse action that clears the throat of mucus or foreign irritants. While an individual coughs to free the throat at intervals, some amount of situations can lead more frequent coughing, which could be as a result of Covid-19.

2. Loss of appetite - This is referred to as anorexia and could be caused by a diversity of conditions and diseases. Some of these conditions could be temporal and rescindable, such as defeat of appetite or a side effect of medicine. Majority of the situations could be very severe, for instance, the consequences of disease causation (could be covid-19). Continuous absence of hunger should be evaluated by a healthcare professional.

3. Difficulty in breathing - This could be described as uneasiness and could be related to numerous diverse conditions. It is important to note that frequent incidents of shortness of breath could be a symptom of a severe illness (such as Corona virus) that needs attention.

4. High temperature/fever - The common body temperature is different for many people and changes during the day. If the body temperature is $38^{\circ} \mathrm{C}$, it is considered as a high fever. Several conditions could lead to fever, but it is usually caused by the body fighting an infection (may be covid-19).

5. Sneezing - This is a sudden reflex discharge of air from the nose and mouth due to irritation of the nostrils, which is caused by exasperation to the mucous membranes of the nose or throat. It may be very inconvenient and could be symptom of Corona virus.

6. Headache - Pain which occurs along the nerves, blood vessels, and muscles that is felt in the head. However, if it persists for 3 days, the doctor should be contacted because it could be an indication of an underlying disease.

7. Fatigue - This could be bodily, mental, or both, an indication which could be difficult to describe; however, words like tired, exhausted, and worn-out may be used.

8. Joint pains - This refers to the uneasiness and pain felt in some joints of the body, such as those of the shoulders, hips, elbows, and knees. Occasionally, joint pain is a result of an illness or injury.

9. Runny nose - This is an indication of several health situations resulting in the flow of secretion from the nostrils. This secretion protects material generated from the slimy tissue that lines the nasal cavity, which mixes with the saliva and drips down the back of the throat. 
10. Sore throat - This is caused by a virus-related contamination, such as cold or influenza. It is also very important that symptoms are appropriately observed.

\section{Preventive Measures of COVID-19}

There are preventive measures recommended to prevent COVID-19 infection, such as self-isolation when feeling sick; avoiding busy spaces; practicing good hygiene; proper handwashing; using alcohol-based sanitizers; maintaining social and physical distancing from others, especially those with symptoms; covering mouth while coughing and sneezing with tissues, which should be thrown properly in a closed dustbin; and preventing from touching the face with unwashed hands. Furthermore, mask should be used outdoor, where additional non-pharmaceutical techniques cannot be adhered, to reduce the rate of transmission (NCDC 2020; WHO 2020).

\section{Strategies Implemented by the Government Globally to Control and Prevent the Spread of COVID-19}

1. Total and partial lockdown for weeks or months of states/regions affected by COVID-19

2. Enforcement of curfew between certain hours of the day to prevent people from going out and contracting the disease

3. Closure of the country/state borders (land, air, and waterways) to prevent further spread of the disease

4. Banning of the interstate movement

5. Fumigation of public places with disinfectants (marketplaces, parking areas, hospitals, congested areas, roads, etc.)

6. Enforcement of the use of surgical gloves, medical masks for healthcare givers, and fabric masks for non-medical personnel

7. Restriction of people's movements to only essential services (healthcare workers, security personnel, and journalists)

8. Opening of markets for some days of the week

9. Distribution of palliatives to the poorest of the poor in the country to enable citizens to fully comply with the total lockdown

However, some of the measures implemented to prevent the spread of the virus, such as fumigation of public spaces with chemicals and the use of personal protective equipment (PPE), which are not properly disposed, can lead to land, water, and air pollution, which will later negatively affect the environment, possibly resulting in environmental challenges and food insecurity and these could be worst in lessdeveloped countries. 


\section{Diagnosis of COVID-19}

The seriousness of the pandemic differs from person to person. COVID-19 infection could show minor sypmtoms, such as ordinary flue or common cold, or no symptoms at all. As the infection progresses, the symptoms change based on gender, generational, and the type of underlying illness. People with mild symptoms of COVID-19 infection usually get better in 14 days or less, although it takes 21 to 30 days to achieve full recovery (NCDC 2020; WHO 2020). Older people or those with underlying diseases, such as hypertension, diabetes, cardiovascular diseases, chronic respiratory diseases, and cancers of any type, are susceptible to this infection (NCDC 2020), while children experience less severe symptoms. The mortality rate of adults less than 50 years who were infected with COVID-19 is less than $0.5 \%$. Conversely, those older than 70 years had the highest mortality rate from the disease. The major problems related with COVID-19 include sepsis, excessive clotting, and damage to the vital organs in the body. Up to $30 \%$ of the individuals infected with COVID-19 exhibited elevated liver enzymes, known as transaminases (Sanders et al. 2020), resulting in organ failiure and eventually death.

\section{Transformation of Situations Causing Typical Climate Change}

Climate change is described as variation on usual climate conditions of an area across periods due to natural circumstances or artificial activities causing degradation of the environment (Nwosu 2012). Climate change is considered as a long-term shift in the average weather situation of a region, such as its typical temperature, rainfall, and wind patterns. This variation in weather indicates that the consequences estimated in a lot of countries will vary over the coming decades.

Weather variations are global phenomenon of climate transformation characterized through fluctuations observed on weather of the planet regarding temperature and precipitation, which are especially instigated through human activities (Food and Agriculture Organisation (FAO) 2002). The balancing of the weather condition to sustain ecosystems is under threat, as well as the future of humanity and the steadiness of the world economy.

In other words, climate change refers to the deviation in the geometric distribution of the average weather circumstances over a prolonged period of time. Climate change induces an increase in the occurrence of extreme weather events. The characteristics of weather variation poses risks to agricultural sustainability and results in food shortage, high level of poverty, and low level of human and physical development. Uninterestingly, weather variations negatively affect human health, water resources, land use, coastal infrastructure, and the environment (International Fund for Agricultural Development (IFAD) 2010), particularly in developing countries, such as Nigeria, where irrigation is not often practiced, as well as in regions that experience heavy rainfall, thus causing extreme flooding and leaching. 
Thus, the apprehension of weather variation cannot be overemphasized which is based on the biggest problem facing the world, affecting everything and everyone, due to the fact that it plays an important environmental influence on ecosystem. Climate change affects the ecosystems in numerous ways, and intermingles with poor growth. The cumulative impacts could lead to intense environmental variations (United States Global Change Research Program (USGCRP) 2009). The severity and frequency of diseases are often related with unfavorable weather conditions and unpredicted health concerns spreading in regions where they have not occurred before.

The consequences of weather variation on the availability, accessibility and stability of food supplies can cause major alterations in people's diet choices, which in turn have consequences on the health of the households and low recovery rate from the pandemic.

Nelson et al. (2018) has reported that climate change is expected to alter global nutrient availability, thereby exerting aftermath effects on malnutrition. The increasing $\mathrm{CO}_{2}$ levels are also expected to reduce the levels of proteins, iron, zinc, and vitamins B1, B2, B5, and B9 in staple foods and docosahexaenoic acid content of fish, which will cause malnutrition to millions of people worldwide after the COVID-19 pandemic (Colombo et al. 2019). COVID-19 pandemic and devastating consequences, and how to stop its spread have become the focus of the world. The greenhouse gases (GHGs) that significantly contribute to climate change, include carbon dioxide, methane, nitrous oxide, ammonia, and other trace gases (Intergovernmental Panel on Climate Change (IPCC) 2007). The other factors causing weather variations are natural causes and human activities. Human activities, such as fumigation and disinfection of public places and improper disposal of used PPEs during the COVID-19 pandemic, also immensely contribute to climate change. The scorching of fossil fuels and the conversion of land for forestry to other uses, including agriculture, are also examples of human activities. Conversely, the natural causes of climate change include variations in ocean currents and atmospheric circulation.

\section{Effects of Weather Variation on the Environment and Agriculture in Nigeria}

The effects of weather variation on food production differ from one country to another which is dependent on the current climate condition affecting agricultural productivity differently. Nigeria, like all the other countries in the sub-Saharan Africa, is highly vulnerable to the impact of climate change. Climate change variations from 1960 and 1999 in parts of Nigeria presented visible incidences of deficiency for a cumulative period of approximately 8-18 years in some parts of Nigeria (Obioha 2009; Muhammed et al. 2011). Uncertainties about the farming season due to the changes in rainfall pattern resulted in crop failure, thus leading to food shortages because of poor harvests. An increase in rainfall is also favorable for 
the outbreak of pests and crop diseases, which is detrimental to crop production. Specifically, pests and crop diseases are visible in response to weather variation, which hypothetically threaten livestock in the drier northern states of Nigeria (Food and Agriculture Organisation (FAO) 2002). Small-scale farmers face the problem of flooding, which destroys the infrastructure used to store or transport food from production areas to markets, thereby discouraging the farmers to produce more food (Aluko et al. 2008). Global warming also negatively affects the seafood and aquatic lives that are important to humans. In addition, climate change affects not only food security but also the livelihood of the people, thus obstructing the advancement of many developing and underdeveloped countries. It is quite obvious that the most serious challenge to agricultural production and mankind worldwide, especially in Africa, is climate change.

\section{Effects of Climate Change on Food Security}

African countries that rely solely on natural resources and rainfed agriculture are more vulnerable to the risks of climate change (IFAD 2010). The consequences of climate change effects are irreversible, potentially disastrous to the entire nation, most especially the developing and underdeveloped nations. For example, it was estimated that by 2020 , agricultural production would decline by $50 \%$ in some countries with rainfed agriculture (Nanki et al. 2010), and this will be worsened by the COVID-19 pandemic. The Intergovernmental Panel on Climate Change (IPCC) in 2008 analyzed that a temperature increase of $2.5^{\circ} \mathrm{C}$ would result in a loss of $1.0-1.5 \%$ of the gross domestic product (GDP) in developed countries and $2-9 \%$ in developing countries. Generally, climate change causes floods, droughts, or tropical storms, which can take a major toll on a country's economy if a significant part of economic activity is sensitive to the weather and climate. Therefore, if the current trend of GHG emissions continues, the per capita GDP loss by 2022 will be as much as 3-35\% (Tamirisa 2008; Harris et al. 2017). Africa is a good example of the influence of climate variability on a developing country's economy (USAID 2010; Zenebe et al. 2011). Boko et al. (2007) and IFAD (2010) reported that the rainfed agriculture and pastoral communities in Africa are dependent on annual rain and were identified to be more susceptible to the effects of climate change. Climate change have negative impacts on food production, especially livestock, in terms of $\mathrm{CO}_{2}$ and methane emissions. Livestock uses about $32 \%$ of arable land, and cattle rearing causes up to $70 \%$ of land degradation and pollution. Therefore, if forests are lost, it will be difficult to fight climate change (Meludu 2019). The sheer quantity of animals being raised for human consumption is a threat to climate sustainability. Another scenario is that 1 ha of land for beef production will feed one person, the same hectare for rice production will feed 19 persons, and the same hectare for potato production will feed 22 persons. This competition is too high to achieve food security and eradicate poverty due to degradation and pollution. 


\section{Concepts of Food Security}

Food security exists at all periods with individuals having financial access to necessary, harmless, and nutritious food that provides adequate requirement for sustainable life expectancy (FAO 2002; Meludu 2009; Meludu and Ewebiyi 2010). Food security and food insecurity are considered to be dynamics that depend solely on causes of not having enough food and the management. However, the partial and total lockdown implemented worldwide due to the COVID-19 pandemic has affected numerous economic activities, such as food distribution, restaurants, hospitality industries, and transportation activities. During the COVID-19 pandemic, many countries closed their borders, preventing the free flow of goods in to different countries and even within the cities. This restriction caused constraints in food distribution and food hoarding, which posed great challenges to food security. This is especially to the vulnerable population including; aged people (senior citizens), children, pregnant women and those with immune-compromised status. Due to the pandemic, food prices have increased worldwide; staple foods such as wheat, garri, rice and beans, tubers, meats, fruits, and vegetables became expensive. Adequate and effective support to encourage unhindered transportation of food items from source locations to various destinations, home deliveries became necessary to reduce human interactions and prevent the possibility of getting infected. When food security is compromised, the consequence is food insecurity.

Food accessibility is affected by the production, distribution, and stability of food (Fig. 1). Food accessibility refers to the easy access to food that is essential to combat hunger and overcome food insecurity. An individual or household's access to food can be influenced by their income and health conditions. Consumers must be able to have the purchasing power in order to have access to food. Due to the COVID-19 pandemic, the rate of unemployment has increased, which resulted in food insecurity. Individuals need to eat sufficiently to develop strong immunity against the virus and to be physically healthy to be able to digest and utilize the nutrients in the food consumed. Food utilization can also be influenced by nutritional values, health status of an individual, safety of the food, and how it is prepared before consumption. Food will be well utilized when people strictly adhere to the important safety precautions against COVID-19. Food stability is guaranteed if the governments worldwide make adequate preparations to reduce the rate of

Fig. 1 Dimension of food security. (Source: Francesco et al. (2011))

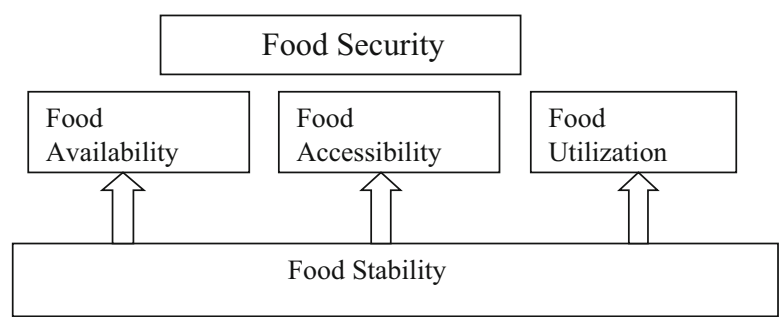


postharvest losses to make food available during this pandemic so that people will remain healthy and safe.

Therefore, to achieve all the highlighted dimensions of food insecurity, the pandemic should be dealt with accordingly to reduce its impacts on climate change so as to avoid food shortage. If adequately managed, the resultant effects will reduce the occurrence of food insecurity globally.

\section{Food Insecurity}

Food insecurity could be considered as deficiency in access to adequate food amount in terms of quality and quantity. Inadequate diet and reduced immune system amplify vulnerability to diseases (Meludu 2011). Low diet is correlated with the increasing development of non-communicable diseases (NCDs) (Velmurugan et al. 2017).

Climate change-related incidents recurring everyday requires immediate action (Solly 2019). Therefore, a scientific innovation strategy for mitigating the impacts of climate chnage on agricultural systems is important. Increased food traceability aimed at preventing food loss due to contamination issues, prediction of extreme events is very germain at this period of pendemic (Dhaliwal and Williams 2019; Fabregas et al. 2018; Nkurunziza et al. 2019).

Food contamination caused by climate change also threatens the achievement of the SDGs, namely SDG 2 (zero hunger), SDG 3 (good health and well-being), SDG 8 (decent work and economic growth), SDG 12 (responsible consumption and production), and SDG 13 (climate action) and indirect effect on the other SDGs. Labor scarcities impacted producers, processors, traders, and distribution companies in food distribution chains necessitate workforces to be in near vicinity. The United Nations World Food Programme (UNWFP) predicted that approximately 265 million people will experience increased food insecurity by the end of 2020.

Food insecurity can be illustrated by durations such as; chronic food insecurity is a longstanding food scarcity. Temporary food insecurity is a momentary circumstance of food insecurity where a populace agonizes from food insecurity transition at the time there is an unexpected drop in the capability to produce food for adequate nutritional status and lastly, Seasonal food insecurity is a condition that could happen from time to time.

Food insecurity "hot spots" according to the UNWFP include the following:

- Substantial conflict-affected states, where food supplies are problematic due to the pandemic. The Fulani nomads are also moving due to climate change which is destroying crops and agricultural land. Uninterestingly, many farmers and their families are displaced from their communities and killed

- Countries experiencing numerous emergencies due to climate change consequences that affect food production worldwide, accompanied by the high incidence of flood preventing farmers from going to their farms to plant 
- Vulnerable individuals constantly experiencing food insecurity even before the pandemic

- Countries with significant currency depreciation and other product price failure (dropping the volume to import food)

\section{Effects of the Coronavirus 2019 (COVID-19) Pandemic and Climate Change on Food Security}

The COVID-19 pandemic has negative effects on climate change which lead to food insecurity. The process of fumigating public places (markets, churches, parking areas, offices, and the entire environment) pollutes the air which eventually affects the weather condition (Fig. 2).

COVID-19 has caused a dramatic loss of human lives worldwide. It also presented an unprecedented challenge with deep social and economic consequences, including food insecurity and malnutrition. An impact on the crusade of labor force and the distribution of inputs has also caused unacceptable constraint to food production. However, agriculture and food-related logistic services was considered to be among the important concerns during the COVID-19 pandemic; thus, food production and distribution should not be compromised.

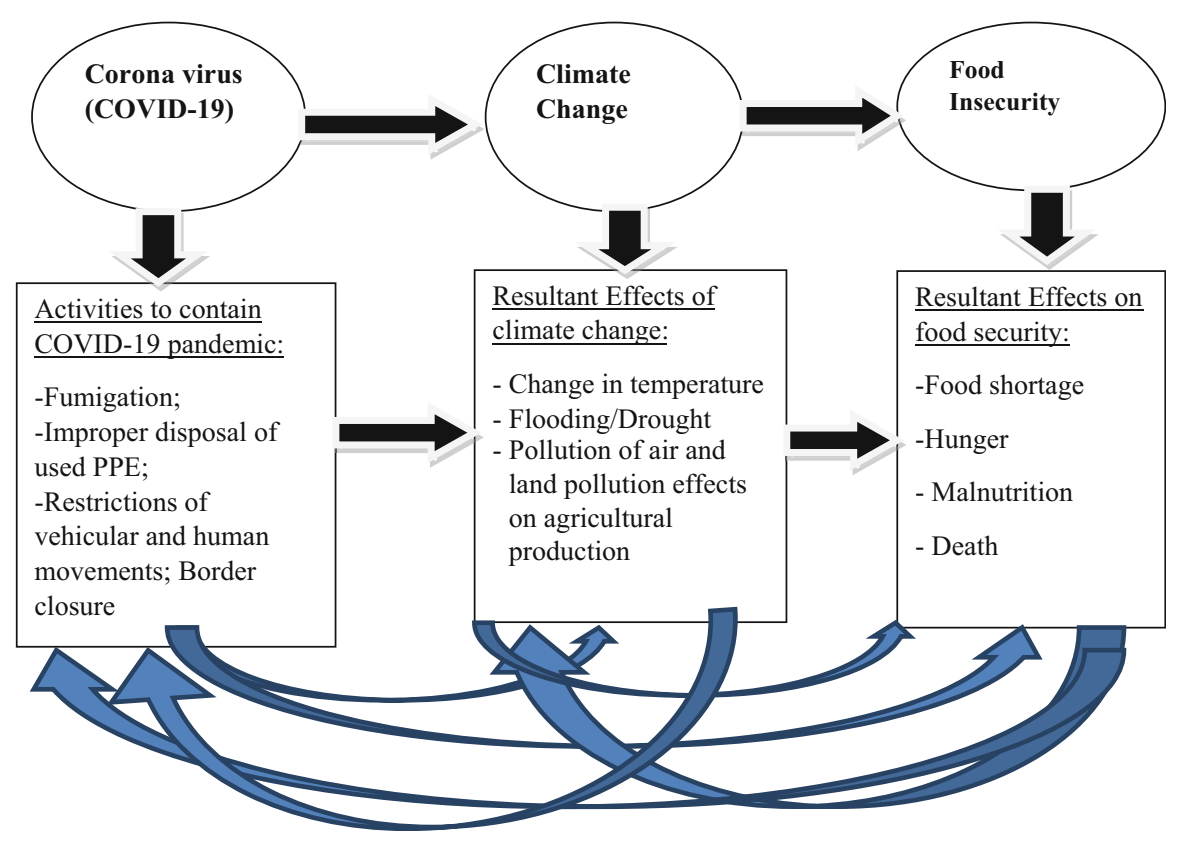

Fig. 2 Conceptual framework of the interface between COVID-19, climate change, and food security 
The government in every country adopted the idea of lockdown as part of the precautionary measures to stop the spread of COVID-19 among its citizens. On the contrary, this lockdown resulted in food shortage in that farmers, marketers, processors, and other stakeholders in the value/supply chain were unable to carry out their enterprise characteristics and the global food system has been destroyed.

\section{Empirical Evidences Obtained Through Online Survey on COVID- 19 Awareness and the Effect on Food Security}

This study used SurveyMonkey (Monkey Survey 2020) to obtain answers to selected questions that were raised with regard to the effects of the COVID-19 pandemic on farming and food security. This study included 514 agricultural stakeholders as participants, of which $55.6 \%$ are male and $44.4 \%$ are female. It is so disappointing to note that many of these participants $(45 \%)$ were not taking COVID-19 very seriously, and some were even unsure whether this disease is real or not. They considered it as politicians or rich man disease. This resulted in nonadherence to the safety measures implemented by the government, thereby causing the rapid spread of the disease. About $60 \%$ of the respondents learned of this pandemic through radio, television, and Internet, $15 \%$ from healthcare workers, $15 \%$ from family members, $5 \%$ from market places, and 5\% from workplaces. This implies that many farmers did not have access to information and communications technologies (Fig. 3) or regular power supply. Thus, only a few people who had sufficient information were able to take adequate measures. This will cause many people to contract the virus, thereby leading to death and affecting agricultural activities which causes food insecurity.

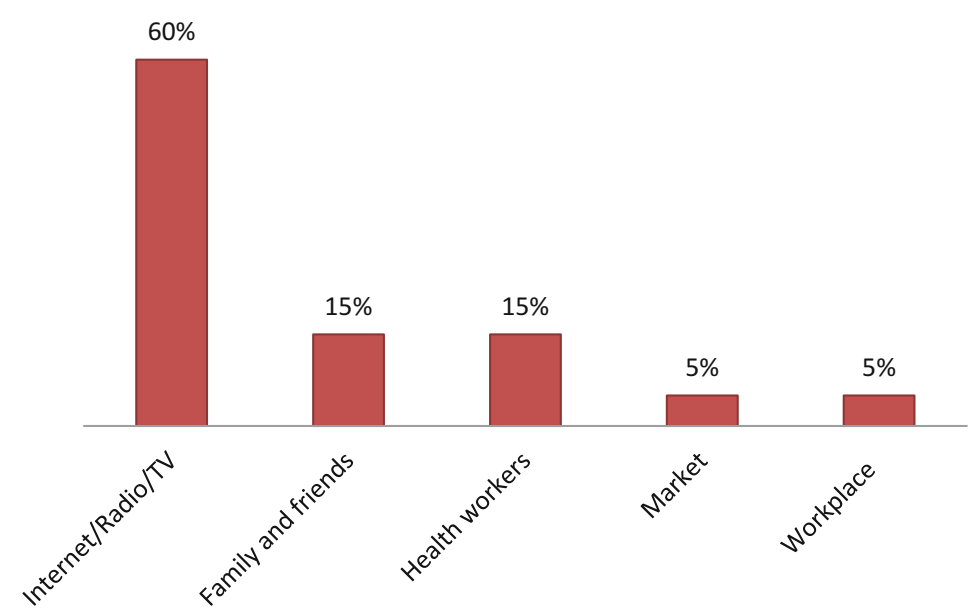

Fig. 3 Channel of information on the COVID-19 pandemic 


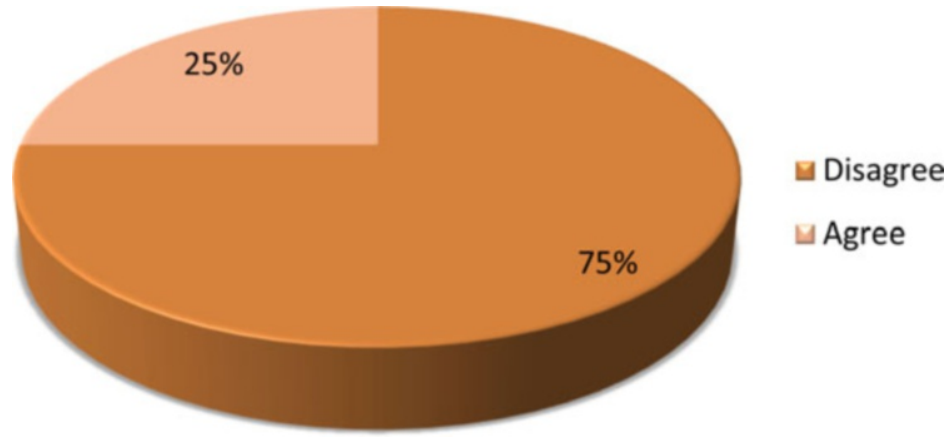

Fig. 4 Farmers' access to palliatives

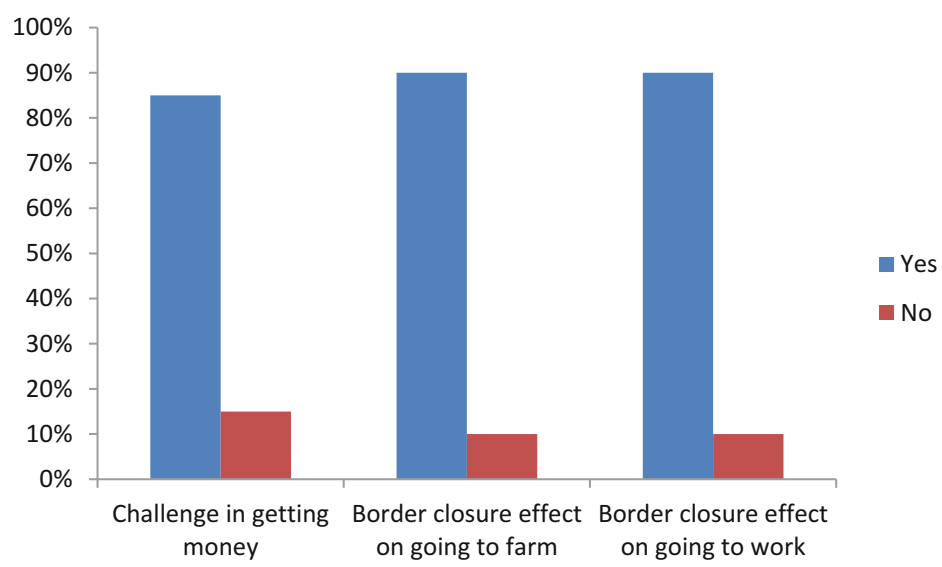

Fig. 5 Effect of COVID-19 on access to money, farm, and office work

During the period of the lockdown to contain COVID-19, when all economic activities were put on hold, many industries could not pay the salaries of their workers; thus, there was either a pay cut or staff layoff. Due to this, the purchasing power was affected and food accessibility became difficult to achieve. Majority $(75 \%)$ of the respondents disagreed with the way the government handled the palliative distribution as not everyone was given, especially the farmers, whereas less than average (25\%) agreed (Fig. 4).

Farmers that were supposed to be on the farm working were asked to stay home as one of the measures to prevent them from contracting the disease. Almost all $(90 \%)$ the farmers adhered to this, and $85 \%$ did not have access to money (Fig. 5). Most crop and livestock farmers in the developing countries rely solely on rainfed agriculture, whereas only few depend on irrigation. Unfortunately, the peak of COVID-19 occurred at the beginning of the rainy season, which is in April. The farmers were unable to perform their seasonal farming activities. Eventually, this will result in food shortage and food insecurity. Transport route blockage hinders the 


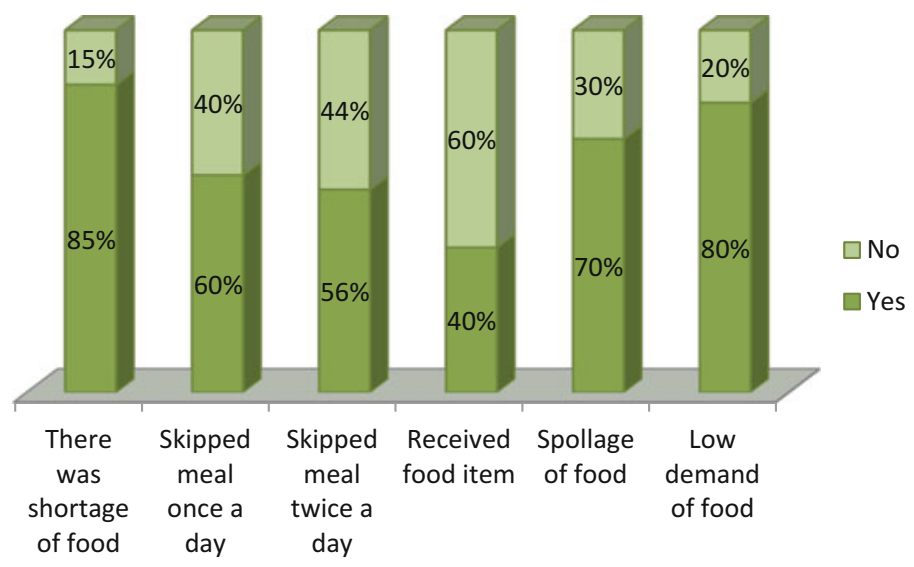

Fig. 6 Distribution of the shortage of food, skipping of meals, food gift, spoilage of agricultural produce, and low demand for food

distribution of fresh goods; thus, high levels of postharvest loss and waste may be experienced.

Marketers play significant roles in ensuring adequate distribution of food products. During the pandemic, marketers were also asked to stay home for a period of weeks or months, depending on the number of index cases recorded in the region. During this period, marketing activities were disrupted as marketers could not buy or sell food as expected. Moreover, there were no available buses/trucks to transport goods and services; interstate borders were also closed. During this, food accessibility was a major challenge for households, thus, eventually leading to food insecurity. Processors are another category of people involve in food distribution. Due to lockdown, the raw materials used for food processing were not available. Therefore, much of foods processing/income were not achieved. This invariably resulted in food shortage and food insecurity and resulted in many $(85 \%)$ households not having access to food. A high percentage of households reported skipping food once $(60 \%)$ or twice $(56 \%)$ a day (Fig. 6). Some crops are supposed to be harvested before the rain in flood-prone areas. However, due to the pandemic, they were left on the ground to spoil (70\%). These measures also resulted in labor shortage which disrupted the production and processing of food, most especially for labor-intensive crops. Migrant workers left to their states, and those who stayed were not allowed to come out, which led to high labor cost even after the relaxation of some measures.

\section{Conclusion}

Climate variation causes events that affect many economies and has been linked to poor food production even before the pandemic. Thus, more effects were felt as part of the pandemic consequences, which led to food shortages. Lockdown and closure of borders led to farm labor shortage and increase in food prices. In addition, the 
amount of food that would have been produced by farmers reduced. Crops harvested by the farmers and ready for sale got wasted on the farm due to the movement restrictions. There were also few trucks available for transporting produces and food products, which led to an increase in transportation costs. Many low-income households, especially in the rural areas, could not afford to buy enough food to sustain the family, thereby causing hunger and malnutrition and lowering their immunity, which made them susceptible to diseases. This pandemic has affected the sustainable development goals toward achieving food security, namely, goal 1: no poverty, goal 2: zero hunger, goal 3: good health and well-being, goal 4: quality education, goal 5: gender equality, goal 6: clean water and sanitation, and goal 7: achieving human development goals and sustaining the ability of natural system to provide natural resources and ecosystem services by 2030 .

\section{Recommendation}

Timely and effective policies should be implemented to prevent more effects on climate variations and also to reduce the consequences of COVID-19 so that extreme poverty and hunger can be avoided. To overcome challenges on food price, an adequate price control mechanism and a price monitoring system for food produce must be in place to evaluate the actions. Quality supervision of food items by the appropriate organs of the government is very important in ensuring food safety and quality, especially during and after the pandemic. Countries are encouraged to produce their own agricultural products. People are now advised to engage in agriculture to reduce the effect of the pandemic on food security.

\section{References}

Aluko AP, Oyeleye B, Sulaiman ON, Ukpe IE (2008) Climate change: a threat to food security and environmental protection. In: Proceedings of the 32 nd annual conference on forestry Association of Nigeria

Boko M, Niang I, Nyong A, Vogel C, Githeko A, Medany M, Osman-Elasha B, Tabo R, Yanda P (2007) Climate Change 2007: impacts, adaptation, and vulnerability. In: Parry ML, Canziani OF, Palutikof JP, van der Linden PJ, Hanson CE (eds) Contribution of working group II to the fourth assessment report of the Intergovernmental Panel on Climate Change. Cambridge University Press, Cambridge, UK, pp 433-467

Colombo SM, Rodgers TFM, Diamond ML, Bazinet RP, Arts MT (2019) Projected declines in global DHA availability for human consumption as a result of global warming. Ambio 37:1-16

Dhaliwal DS, Williams MM (2019) Optimum plant density for crowding stress tolerant processing sweet corn. PLoS One 14(9):e0223107. [online]. Accesses 25 May 2020

Fabregas N, Lozano-Elena F, Blasco-Escamez D, Tohge T, Martinez-Andujar C, Albacete A, Osorio S, Bustamante M, Riechmann JL, Nomura T, Yokota T, Conesa A, Alfocea FP, Fernie AR, Canno-Delgado AI (2018) Over expression of the vascular brassinosteroid receptor BRL3 confers drought resistance without penalizing plant growth. Nat Commun 9(1):4680

FAO (2002) Report of the world food summit five years after. FAO, Rome

Francesco B, Jessica F, Emile F (2011) The role of food and nutrition system approach in tackling hidden hunger. Int J Environ Res Public Health 8:358-373 
Harris JM, Roach B, Anne-Marie C (2017) The economics of global climate change. A GDAE Teaching Module on Social and Environmental Issues in Economics. Global Development and Environment Institute, Tufts University Somerville

Hui DS, Azhar E, Madani TA, Ntoumi F, Kock R, Dar O (2020) The continuing 2019-nCoV epidemic threat of novel corona viruses to global health. Int J Infect Dis 91:264-266

IFAD (2010) Livestock and climate change Livestock. The International Fund for Agricultural Development (IFAD) Livestock Thematic Papers. http://www.ifad.org/lrkm/factsheet/cc.pdf. Accessed 9 Aug 2013

IPCC (2007) Summary for policymakers. In: Solomon S, Qin D, Manning M, Chen Z, Marquis M, Averyt KB, Tignor M, Miller HL (eds) Climate change 2007: The physical science basis. Contribution of working group I to the fourth assessment report of the Intergovernmental Panel on Climate Change. Cambridge University Press, Cambridge, UK/New York

Meludu NT (2009) Food insecurity and nutritional status of children in rural households (A case of Iddo LGA, Oyo State). Niger J Soc Work Educ 8:40-60

Meludu NT (2011) Farmers' awareness and utilization of disaster management strategies and training needs for sustainable food security and livelihoods in Nigeria. In: Brebbia CA, Kassab AJ, Divo EA (eds) Disaster management and human health risk II: reducing risk, improving outcomes. WIT Press, Southampton/Boston, pp 303-319

Meludu NT (2019) Communicating knowledge of climate change in achieving zero hunger sustainable development goal (SDG). Paper presented at the one day media round table discussion to the University on Communicating Knowledge on Climate Change Information for Sustainable Decision Making in Nigeria. By Centre for Sustainable Development Nnamdi Azikiwe University, Awka May, pp 1-4

Meludu NT, Ewebiyi IO (2010) Policy development and opportunities in ICT for sustainable food and nutrition security in Nigeria. Afr J Psychol Stud Soc Issues 13(1):137-151

Monkey Survey (2020) Survey Monkey, San Mateo, pp 1-23. http://www.surveymonkey.com. Accessed 5 May 2020

Muhammed G, Jaliye MM, Usman S, Baniwa E (2011, March) Adaptive strategies to climate change variability and change in rural communities. In: Proceedings of the 16 th annual national conference of agricultural extension of Nigeria (AESON)

Nanki K, Million G, Beneberu S, Zegeye T, Gebeyehu S, Endale A (2010) Adapting to climate change in the water sector: assessing the effectiveness of planned adaptation interventions in reducing local level vulnerability. RiPPLE. Water-Aid-Ethiopia, Addis Ababa

NCDC (2020) Covid-19 Nigeria. Available at ncdc.gov.ng. Accessed 7 June 2020

Nelson G, Bogard J, Lividini K, Arsenault J, Riley M, Sulser TB, Mason-D'Croz D, Power B, Gustafson D, Herrero M, Wiebe K, Cooper K, Remans R, Rosegrant M (2018) Income growth and climate change effects on global nutrition security to mid-century. Nat Sustain 1(12):773778

Nkurunziza L, Chirinda N, Lana M, Sommer R, Karanja S, Rao I, Romero Sanchez MA, Quintero M, Kuyah S, Lewu F, Joel A, Nyamadzawo G, Smucker A (2019) The potential benefits and trade-offs of using sub-surface water retention technology on coarse-textured soils: impacts of water and nutrient saving on maize production and soil carbon sequestration. Front Sustain Food Syst 3. https://doi.org/10.3389/fsufs.2019.00071

Nwosu LE (2012, March) Climate change and food security: implication for effective agricultural extension services in Nigeria. In: Proceedings of the 17 th annual national conference of agricultural extension of Nigeria (AESON)

Obioha EE (2009) Climate variability, environmental change and food security nexus in Nigeria. J Hum Ecol 26(2):107-121

Oliva R, Ji C, Atienza-Grande G, Huguet-Tapia JC, Perez-Quintero A, Li T, Eom J-S, Li C, Nguyen H, Liu B, Auguy F, Sciallano C, Luu VT, Dossa GS, Cunnac S, Schmidt SM, Slamet-Loedin IH, Vera Cruz C, Szurek B, Frommer WB, White FF, Yang B (2019) Broad-spectrum resistance to bacterial blight in rice using genome editing. Nat Biotechnol 37(11):1344-1350 
Report of WHO-China Joint Mission on Corona Virus Disease 2019 (COVID-19). 16-24 February 2020. Accessed 3 May 2020

Sanders JM, Monogue ML, Jodlowski TZ, Cutrell JB (2020) Pharmacologic treatment for Corona virus diseases 2019. A Review. PMID: 32282022. https://doi.org/10.1001/jama.2020.6019

Solly M (2019) One climate crisis disaster occurs every week, UN official warns. Smithsonian Magazine, 8 July 2019. https://www.smithsonianmag.com/smart-news/un-expert-warnsoneclimate-crisis-disaster-occurs-every-week-180972573

Tamirisa N (2008, March) Climate change and the economy. Finance \& Development. http://www. imf.org/external/pubs/ft/fandd/2008/03/pdf/tamirisa.pdf. Accessed 23 Apr 2020

United Nations Department of Economic and Social Affairs (2015) Sustainable development goals. Available at http://www.un.org/sustainabledevelopmentmaterials. Accessed 21 May 2020

United States Global Change Research Program (USGCRP) (2009) Global climate change impacts in the United States. In: Karl TR, Melillo JM, Peterson TC (eds) United States global change research program. Cambridge University Press, New York

USAID (2010) Adapting to climate variability and change a guidance manual for development planning. http://pdf.usaid.gov/pdf_docs/PNADJ990.pdf. Accessed 9 Apr 2020

Velmurugan, G., Ramprasath, T., Gilles, M., Swaminathan, K. And Ramasamy, S. (2017). Gut microbiota, endocrine-disrupting chemicals, and the diabetes epidemic. Trends Endocrinol Metabol, 28(8): 612-625. https://doi.org/10.1016/j.tem.2017.05.001

World Health Organization (2020) WHO Director-General's opening remarks at the media Briefing on COVID-19 (Press release) 11 March 2020. "Advice for Public"

Zenebe G, Stage J, Alemu M, Atlaw (2011) Climate change and the Ethiopian economy. A computable general equilibrium analysis: environment for development discussion paper series October 2011, EfD DP 11-09. http://www.rff.org/RFF/Documents/EfD-DP-11-09.pdf http:// www.vanguard.com/2020/04/covid-19-maintaining-food-security-in-crisis-situations.

Accessed 9 Aug 2019

Open Access This chapter is licensed under the terms of the Creative Commons Attribution 4.0 International License (http://creativecommons.org/licenses/by/4.0/), which permits use, sharing, adaptation, distribution and reproduction in any medium or format, as long as you give appropriate credit to the original author(s) and the source, provide a link to the Creative Commons license and indicate if changes were made.

The images or other third party material in this chapter are included in the chapter's Creative Commons license, unless indicated otherwise in a credit line to the material. If material is not included in the chapter's Creative Commons license and your intended use is not permitted by statutory regulation or exceeds the permitted use, you will need to obtain permission directly from the copyright holder.

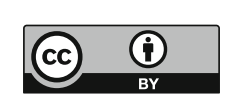

